\title{
SIMBOL TRI MURTI \\ DALAM PAYAS AGUNG PENGANTIN BALI
}

\author{
Oleh : \\ Ida Ayu Gede Prayitna Dewi \\ Dosen Fakultas Pendidikan Agama dan Seni UNHI
}

\begin{abstract}
:
Balinese fashion and dress is one part of Balinese culture with elements of art that have existed in antiquity. The kings of Bali of his day have introduced a distinctive dress culture in their respective regions of power. Some types of Balinese have similarities and differences in forms such as Payas Agung Karangasem, Buleleng, Tabanan, and Badung. Payas Agung The Bali Bridal used to be a dress for the King and queen, but over time now Payas Agung Bridal Bali is used for the wedding of Balinese people in general. The emergence of new make-up artists has made a positive impact in the development of Makeup in Bali, but a study that can be used as a guideline for the tradition of makeup and the value of philosophy is not lost and well preserved. This research is a qualitative type with the theory of symbols, aesthetic theory and religious theory. The research techniques are conducted by observation and interviews, document studies. The results obtained are Cempaka flowers and kenanga is a symbol of Tri Murti in Payas Agung Bridal Bali is placed on the head decoration, where this section is the most purified as the embodiment of offerings to Ida Sang Hyang widhi Wasa. The value contained and the influence of this symbol on the bride is as a form of beauty and Taksu.
\end{abstract}

Keywords: Tri Murti, Balinese Payas Agung

\section{PENDAHULUAN}

Berbicara mengenai Budaya Bali tentunya masih tetap menjadi hal yang menarik untuk diperbincangkan dan dikaji dalam berbagai bentuk, baik lisan maupun tulisan. Kenyataan yang terjadi dalam masyarakat dewasa ini adalah semakin banyak budaya yang menyimpang bahkan terhapus dan tidak berada dalam kaedah yang sebenarnya. Hal ini terjadi tentu saja karena adanya pengaruh budaya luar Bali yang membaur dalam kehidupan orang- orang Bali Kini, sehingga pemikiran yang global dan universal selaras dengan kehidupan kekinian masyarakat Bali. Budaya yang kini berkembang dalam kehidupan masyarakat Bali masih dapat dipertahankan oleh masyarakat Bali sendiri tanpa menutup diri namun menerimanya secara terbuka dengan tetap menjadikan Budaya asli sebagai kebanggaan tersendiri. Keunikan Budaya Bali dapat tergambar jelas dalam hal kesenian yang telah tersohor di dunia sejak jaman dahulu. Kini masyarakat Bali bertugas untuk mempertahankannya dengan baik dan tetap memiliki rasa tanggung jawab terhadap Budaya dan kesenian tersebut. Tata Rias dan Busana adat Bali adalah salah satu bagian Budaya Bali dengan unsur Seni yang telah ada pada jaman dahulu. Rajaraja di Bali pada masanya telah memperkenalkan budaya berbusana yang khas di masing- masing daerah kekuasannya. Beberapa jenis Payas Agung Bali memiliki persamaan dan perbedaan bentuk seperti Payas Agung Karangasem, Buleleng, Tabanan, maupun Badung. Payas Agung Pengantin Bali dahulu digunakan sebagai busana untuk kalangan kerajaan, namun seiring jaman kini Payas Agung Pengantin Bali digunakan untuk pernikahan masyarakat Bali pada umumnya.

Dalam perkembangannya Payas Agung Bali kini mengalami beberapa perubahan bentuk yang dapat dikatakan sangat signifikan bahkan merubah makna yang telah ada. Kreatifitas penata rias yang muncul dewasa ini secara tidak sadar telah mengurangi bahkan menghilangkan makna- 
makna yang seharusnya dipertahankan, mengingat seni yang ada merupakan simbol- simbol yang dijadikan wujud dari makna tersebut. Hal ini terjadi karena kurangnya pemahaman dan pengetahuan mengenai simbol dan nilai filosofis busana yang digunakan. Payas Agung Bali jika didalami arti dan makna serta filosofi yang terkandung didalamnya, dapat kita lihat dan cermati bahwa busana ini memiliki nilai pendidikan estetis dan nilai religius yang dapat membentuk pemahaman moral dan pembentukan karakter masyarakat Bali.

Kemunculan desain- desain Busana adat Bali modern memberikan warna tersendiri dalam perkembangan Busana Bali, seperti tata cara memakai kain, selendang bahkan riasan kepalanya. Berkembangnya jaman dan bertambahnya kreatifitas penata rias Bali, kini menghadirkan pula beberapa jenis busana pengantin, seperti rias modifikasi ( biasanya untuk resepsi ). Hal ini merupakan sebuah perkembangan yang baik karena dapat memberikan warna khasanah seni dalam Tata Rias dan Busana Bali. Namun perlu diperhatikan bahwa kreatifitas yang bersumber dari tradisi dan budaya Bali yang adi luhung, tentunya harus tetap menjaga makna dan filosofi yang terdapat dalam tradisi tersebut. Beberapa seminar dan pelatihan Rias Pengantin Bali dilaksankan secara umum dan berkelanjutan oleh beberapa lembaga kecantikan yang ada di Bali merupakan bentuk pelestarian dan upaya mempertahankan bentuk asli atau Pakem Payas Pengantin Bali.

Payas Agung Pengantin Bali memiliki bentuk yang unik dan mengandung nilai estetik yang tinggi, baik dari segi wujudnya maupun prosesnya. Dari ujung kepala sampai ujung kaki memiliki arti dan filosofi yang terkait dengan tata cara atau aturan yang baik dalam menempuh kehidupan perkawinan. Proses dalam pemakaian Payas Agung Pengantin Bali juga memiliki beberapa tahapan yang mencerminkan kesiapan pengantin dalam memasuki kehidupan perkawinan kedepannya.

Penggunaan hiasan kepala atau mahkota dalam Payas Agung Pengantin Bali merupakan hal yang paling disucikan dan dipercaya menjadi puncak kecantikan pada wanita yang menggunakan busana ini. Bentuk hiasan kepala ini biasanya terbuat dari emas atau perak yang ditata dengan beberapa elemen dengan nilai estetika yang sangat tinggi. Selai memakai bahan tersebut, juga menggunakan bunga segar berupa bunga cempaka putih, cempaka kuning, bunga kenanga dan bunga mawar. Penggunaan bunga segar ini secara sederhana memberikan kesan indah, segar dan harum karena memang asli. Namun selain hal tersebut, bunga segar yang digunakan memiliki arti dan terdapat nilai filosofi Hindu yang tinggi. Bunga Cempaka dan kenanga dalam upacara agama Hindu sering digunakan sebagai sarana persembahyangan dan persembahan, karena bentuk bunganya yang indah dan harum. Begitu pula dalam busana Pengantin Bali, Bunga Cempaka dan Kenanga merupakan simbol Tri Murti, yaitu Tiga dewa manifestasi Tuhan dalam Ajaran Agama Hindu.

\section{METODELOGI PENELITIAN}

\section{Rancangan Penelitian}

Suatu penelitian ilmiah dimulai dengan perencanaan yang seksama dan sistematis. Dalam penelitian ini dipergunakan rancangan penelitian Kualitatif yang menggunakan data- data lapangan berupa wawancara dan observasi langsung ke tempat atau lokasi penelitian. Dalam penelitian ini objek yang diteliti mengarah pada pola budaya yang menekankan pada fenomena sehingga analisis data yang digunakan adalah analisis deskriptif, yaitu dengan mengadakan suatu telaah pada suatu gejala yang bersifat objektif sesuai dengan data kepustakaan maupun lapangan yang menjadi objek penellitian, sehingga merupakan sebuah bentuk tulisan yang bertalian dengan usaha untuk melukiskan sebuah rincian dari objek yang sedang dibicarakan ( Ndraha, 1981:125). Telaah yang dilakukan adalah mengkaji dari segi bentuk, fungsi dan makna simbol Agama Hindu dalam Payas Agung Pengantin Bali. Penelitian kualitatif dilakukan dengan mengadakan observasi langsung ke lapangan dan mencari nara sumber yang berkompeten. Penyajian hasil data dilapangan tersebut dirangkum secara deskriptif yaitu pemaparan atau gambaran dan penjelasan 
yang diperoleh dituangkan ke dalam bentuk tulisan. Dalam penelitian ini objek yang diteliti mengarah pada pola budaya yang menekankan pada fenomena sehingga analisis data yang digunakan adalah analisis deskriptif.

\section{Sumber Data}

Menurut Ridwan (2004:40) data merupakan bahan mentah yang sangat diperlukan di dalam aktifitas penelitian dan perlu diolah sehingga menghasilkan informasi. Dilihat dari jenisnya terdapat dua jenis data yaitu data Kualitatif dan data kuantitatif. Data kualitatif merupakan data yang menunjukan kualitas atau mutu yang bentuknya berupa informasi secara tertulis dan informasi lisan. Sedangkan data kuantitatif yaitu data yang berupa jumlah atau deretan angka- angka seperti statistik atau skor.

Penelitian dengan jenis Kualitatif merupakan jenis penelitian yang tidak menggunakan prosedur statistik atau penghitungan seperti penelitian kuantitatif. Metode kualitatif merupakan suatu prosedur penelitian yang menghasilkan data diskriftif berupa kata tertulis atau ajaran dari seseorang dan atau suatu perilaku aktor maupun objek tertentu yang bisa diamati oleh peneliti ( Atmaja, 2002 ). Untuk menunjang penelitian dengan jenis Kualitatif, dibutuhkan data yang merupakan sekumpulan nilai dan fakta yang dikumpulkan melalui pengumpulan data yang sah. Fakta merupakan hasil pertanyaan kepada nara sumber dalam sebuah wawancara yang telah diverifikasi secara empirik. Ada dua data yang terdapat dalam penelitian ini yaitu Data Primer data yang dikumpulkan dan diperoleh dengan melakukan observasi langsung di lapangan serta melakukan wawancara kepada nara sumber, seperti Penata Rias Pengantin Bali, Budayawan, dan Seniman . Nara sumber tersebut memberikan data dari hasil wawancara dan praktek langsung mengenai teknik ( Pakem) Payas Agung Pengantin Bali. Data Sekunder yaitu data yang dikumpulkan melalui buku- buku dan sejenisnya sebagai referensi yang relevan dengan penelitian. Data diperoleh dari buku, artikel, Jurnal, Modul dan bahan bacaan lainnya tentunya yang memberikan pemikiran yang berhubungan dengan penelitian yang dilaksanakan dan menambah wawasan umum mengenai permasalahan yang diangkat dalam penelitian.

\section{Teknik Pengumpulan Data}

Penelitian merupakan suatu rangkaian kegiatan ilmiah, baik pengnumpulan data, mengolah data, menarik kesimpulan atas gejalagejala tertentu, menguji kebenaran teori. Teknik pengumpulan data merupakan cara kerja yang terkait dengan apa yang harus diperbuat dan bagaimana berbuat dalam rangka mencapai tujuan penelitian ( Sudikan,2001:770 ).

Dalampenelitian Kualitatifterdapatbeberapa teknik pengumpulan data yang menekankan pada teknik observasi, wawancara dan studi dokumen.

\section{Teknik Observasi}

Observasi merupakan metode yang memungkinkan peneliti mengamati dari dekat gejala penelitian, dalam hal ini peneliti dapat mengambil jarak sebagai pengamat semata- mata atau dapat pula melibatkan diri di dalam situasi yang diselidiki ( Srakhmad, 1989: 165 ). Observasi adalah teknik pengumpulan data yang diperoleh dengan cara mengadakan pengamatan langsung ke tempat objek yang akan diteliti.

\section{Teknik wawancara}

Wawancara adalah percakapan dengan maksud tertentu yang dilakukan oleh dua pihak yakni pihak pewawancara (intervewer) dan terwawancara ( interview) yang member jawaban atas pertanyaan ( Moleong, 2006: 203). Wawancara merupakan teknik pengumpulan data yang menggunakan seorang atau lebih nara sumber untuk mendapatkan informasi yang akurat mengenai objek penelitian. Menurut Mulyana ( 2001 : 180- 181) wawancara adalah bentuk komunikasi antara dua orang, melibatkan seseorang yang memperoleh informasi dari seseorang lainnya dengan mengajukan pertanyaan- pertanyaan berdasarkan tujuan tertentu. Wawancara dapat dibagi menjadi dua yaitu: (1) wawancara berencana atau Standardized Interview dan (2) wawancara tak berencana atau Untardardized Interview. Dalam penelitian 
Tari Pendet, digunakan kedua teknik wawancara dengan informan yang berkompeten dan memahami tentang tarian dan kaitannya dengan Upacara yang dilaksanakan. Wawancara dilakukan dengan Bendesa Adat, Pemangku, Seniman atau Budayawan, Praktisi Tata Rias dan Busana Adat Bali dan beberapa sumber yang terkait.

Menurut Yin ( 2000:108-109) menyatakan bahwa wawancara bisa mengambil beberapa bentuk, dan yang umum digunakan dalam studi kasus adalah wawancara bertipe open ended. Dalam wawancara tersebut peneliti dapat bertanya kepada nara sumber atau informan kunci mengenai fakta- fakta dari peristiwa yang ada. Dalam beberapa situasi peneliti dapat meminta pendapat sendiri dari informan terhadap peristiwa tertentu dan menggunakan posisi tersebut sebagai dasar penelitian selanjutnya.

Sebelum melakukan wawancara penulis mempersiapkan pedoman wawancara agar dalam pelaksanaannya terarah dan efisien. Wawancara dilakukan dengan nara sumber yang berkompeten atau yang terkait dengann dengan penelitian ini yaitu wawancara dengan Tokoh Masyarakat, seniman, praktiasi tata rias Busana Adat Bali.

\section{Teknik Dokumentasi}

Dokumentasi adalah sebuah metode untuk mencari data mengenai variable yang diteliti ( Arikunto, 22: 206 ). Dokumentasi dalam penelitian Tari rejanng Pulu menggunakan alatalat penunjang seperti Kamera Foto, Handycam, dan dalam bentuk tertulis. Dokumentasi tersebut dikumpulkan dengan cara merekam (Audio Visual ), menggunakan Foto- foto teknik pemasangan Payas Agung Pengantin Bali.

\section{Instrumen Penelitian}

Dalam penelitian kualitatif, peneliti adalah instrument utamanya. Sebagai instrument utama telah dipersiapkan kelengkapan- kelengkapan yang diperlukan dalam penelitian.kelengkapan yang disiapkan diantaranya membuat daftar pertanyaan yang akan ditanyakan kepada informan dalam wawancara. Instrument penunjang lainnya juga telah dipersiapkan, seperti Tape recorder, Alat pencatatan, Handycam, dan kamera foto untuk mendokumentasikan dan mencatat, merekam informasi yang akan diperoleh dari hasil wawancara dengan informan atau nara sumber.

\section{PEMBAHASAN}

\section{Payas Agung Pengantin Bali}

Payas Agung merupakan sebuah Tata busana adat Bali yang digunakan pada pengantin Bali, yaitu dalam upacara perkawinan ( Pawiwahan) dengan adat Bali. Payas Agung menjadi tata busana yang tingkatannya paling tinggi disesuaikan dengan upakara dan upacara yang diselenggarakan. Dalam upacara perkawinan ( Pawiwahan ) adat Bali, payas Agung digunakan dalam tingkatan upacara yang paling tinggi dalam sebuah prosesi upacara perkawinan Adat Bali. Tingkatan tertinggi dalam upacara perkawinan Adat Bali disebut dengan upacara Mewidhi Widana yang merupakan penyempurnaan di dalam melaksanakan upacara perkawinan untuk meningkatkan pembersihan yang telah dilakukan pada tahapan sebelumnya, yaitu upacara mekalan kalan. Upacara mekalan- kalan atau juga disebut medengen- dengen merupakan bagian penting dalam rangkaian upacara perkawinan, dimana dilakukan pembersihan terhadap kedua mempelai, dan upacara ini dipimpin oleh pemangku. Upacara Mewidhi widana merupakan upacara yang penting pula dalam rangkaian upacara perkawinan, dimana upacara ini dipimpin oleh sulinggih / Ida Pedanda. Dalam upacara inilah busana Payas Agung digunakan dengan beberapa prosesi yang dilaksanakan dari semalam sebelumnya hingga pagi hari saat upacara dilaksanakan. Bali memiliki beberapa jenis Payas Agung Pengantin yang terdapat di beberapa daerah - daerah di Bali, seperti Badung, Tabanan, Karangasem, Buleleng, termasuk Gianyar. Masing- masing Payas Agung ini memiliki beberapa perbedaan yang menonjolkan beberapa keunikan sesuai dengan daerah dan lingkungannya. 


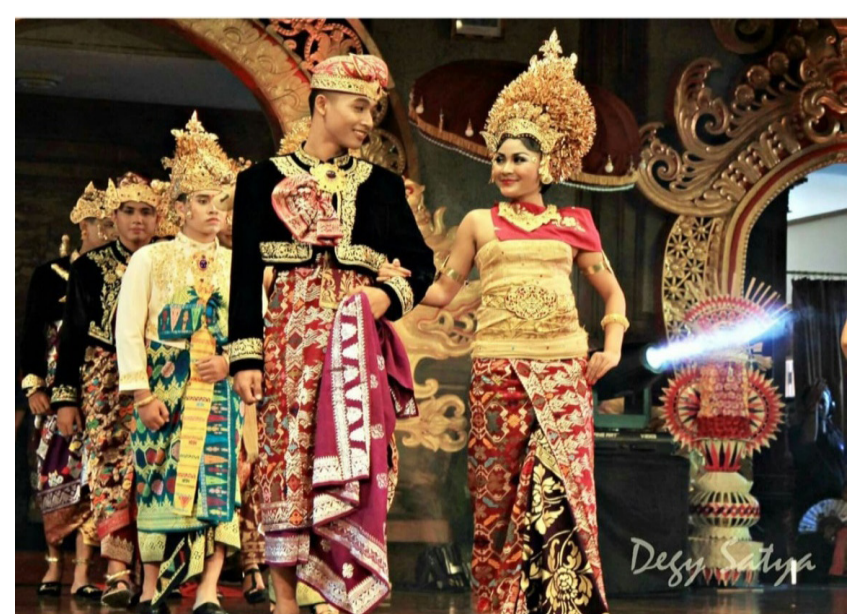

Foto 1. Payas Agung Pengantin Bali gaya Gianyar

\section{Simbol Tri Murti dalam Payas Agung Bali}

Perwujudan kreativitas seni dalam masyarakat Bali dikembalikan pada Tri Murti, yaitu manifestasi Ida Sang Hyang Widhi Wasa dalam wujud Tiga Dewa dengan tugas dan fungsinya masing- masing, yaitu Dewa Brahma ( Pencipta ), Dewa Wisnu ( Pemelihara ), dan Dewa Siwa ( Pelebur ). Masyarakat Bali memberikan penghormatan tersebut dan diwujudkan dalam sebuah kreativitas seni yang juga ditujukan dalam semua aspek kehidupan termasuk dalam menghasilkan kesenian ( Bandem, 1996 : 1 ). Dalam payas Agung Bali pada umumnya menggunakan Bunga cempaka dan kenanga yang merupakan simbolisasi Tri Murti dalam kaitannya dengan upacara keagamaan yang dilakukan. Warna sebagai penanda terdapat dalam Bunga Cempaka kuning yang menjadi lambang Dewa Brahma, Bunga Cempaka putih menjadi lambang Dewa Siwa, dan Bunga Kenanga menjadi lambang Dewa Wisnu. Ketiga perlambangan Dewa ini dirangkai menjadi satu dan diletakkan pada bagian kepala dimana menjadi sebuah lambang kesucian, dalam Agama Hindu dikenal konsep Tri Angga. Konsep Tri Angga dalam tubuh manusia ( Bhuana Alit ) dibedakan menjadi tiga bagian, yaitu Utama Angga ( kepala), Madya Angga ( Badan ), dan Nista Angga ( Kaki ). Bagian Utama Angga atau bagian Kepala adalah bagian yang paling disucikan dalam tubuh manusia, begitupula pada Tata Rias Busana Bali, khususnya Payas Agung Pengantin Bali menempatkan Bunga di bagian kepala yaitu Utama Angga sebagai suatu hal yang paling disucikan. Keterkaitan konsep Tri Angga dan Simbol Tri Murti dalam Payas Agung Pengantin Bali adalah terletak dalam penempatan atau pemasangan bunga cempaka dan kenannga sebagai simbol Tri Murti yang tentunya diletakkan pada tempat yang paling disucikan sebagai perwujudan atau persembahan yang tertinggi kepada Tuhan dalam manifestasinya sebagai Tri Murti.

Keberadaan simbol Tri Murti dalam Payas Agung Pengantin Bali merupakan implementasi keyakinan, kepercayaan dan ajaran Agama Hindu di Bali yang mengenal adanya perlambangan Dewa- Dewa sebagai perwujudan Ida sang Hyang Widhi wasa sesuai dengan tugasnya masingmasing. Tri Murti merupakan tiga kekuatan Brahman ( Sang Hyang Widhi Wasa) dalam menciptakan, memelihara, melebur alam semesta beserta isinya. Tri Murti terdiri dari Dewa Brahma yang berfungsi sebagai pencipta / Utpathi denngan saktinya Dewi Saraswati yang merupakan Dewi Ilmu Pengetahuan memiliki warna Merah. Dewa Wisnu berfungsi sebagai pemelihara / Sthiti dengan saktinya Dewi Laksmi atau Dewi Sri , memiliki perlambangan warna Hitam. Dewa Siwa sebagai pelebur / Pralina dengan saktinya Dewi Durga/ Uma / Parwati memiliki perlambangan warna Panca warna yang salah satunya adalah warna Putih.

Keberadaan bunga cempaka dan kenanga dalam Payas Agung Pengantin Bali memiliki nilai filosofi yang tinggi, tidak hanya sebgai perwujudan $\mathrm{n}$ ilai keindahan atau kreativitas seni saja, namun lebih kepada pemaknaan atas simbol- simbol yang telah dipikirkan sebelumnya. Dalam Agama Hindu, bunga memiliki arti dan fungsi tersendiri terkait dengan upacara dan upakara yang ada di dalamnya. Ada dua fungsi bunga yang penting dalam upacara, yaitu sebagai simbol Tuhan dan sebagai sarana persembahyangan. Bunga sebagai 
simbol Tuhan tampak dalam filosofi Tri Murti dalam Payas agung Pengantin Bali, yang diyakini dan disucikan berdasarkan letak penggunaanya, yaitu di bagian kepala ( Utamaning Angga) yang dalam konsep Tri Angga sebagai hal yang paling disucikan, bersifat sakral dan magis. Kaitannya dengan konsep Estetika Hindu adalah, pemakaian bunga ini sebagai simbol Tri Murti adalah konsep Kesucian ( Shiwam ) dimana simbol ini sebagai perwujudan ketulus iklasan kepada Tuhan yang suci.

Dalam sebuah lontar Yadnya Prakerti disebutkan: "sekare pinake katulusan pikayunan suci " artinya Bunga itu sebagai lambang ketulus iklasan pikiran yang suci. Dalam Bhagawadgita Bab IX sloka 26 menyebutkan unsur- unsur pokok persembahyangan yang ditujukan kepada Ida Sang Hyang Widhi Wasa di samping daun, buah dan air. Adapun bunyi sloka tersebut adalah :

Pattram Puspam Phalam Toyam

Yo Me Bhaktya Prayacchati

Tad Aham Bhaktyupahrtam

Asnami Prayatatmanah

\section{Artinya:}

Siapapun yang dengan kesujudan mempersembahkan kepadaku daun, bunga, buah- buahan, air, persembahan yang didasari oleh cinta dan keluar dari lubuk hati yang suci aku terima.

Bunga yang baik digunakan dalam persembahan adalah bunga yang memiliki wangi harum, tidak busuk dan berulat dan memiliki nilai filosofi yang terkait dengan cerita- cerita religius. Mengenai arti dan makna bunga sebagai sarana yang digunakan dalam upacara keagamaan memiliki makna yang sangat penting. Sebagai sarana pemujaan artinya sebagai sarana yang digunakan untuk memuja serta mewakili ungkapan hati yang tulus iklas memuja sebagai ungkapan terima kasih kepada Ida Sang Hyanng Widhi Wasa. Bunga digunakan sebagai simbol perwujudan dari Ida Sang Hyang Widhi Wasa dengan segala Prabawanya ( Miarta, 2009 : 83 ).

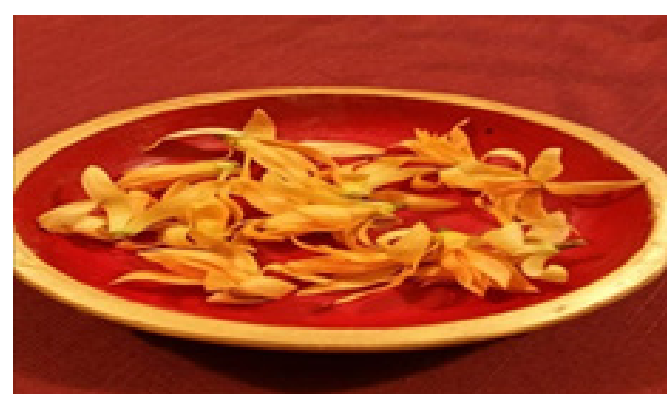

Foto2. Bunga cempaka kuning

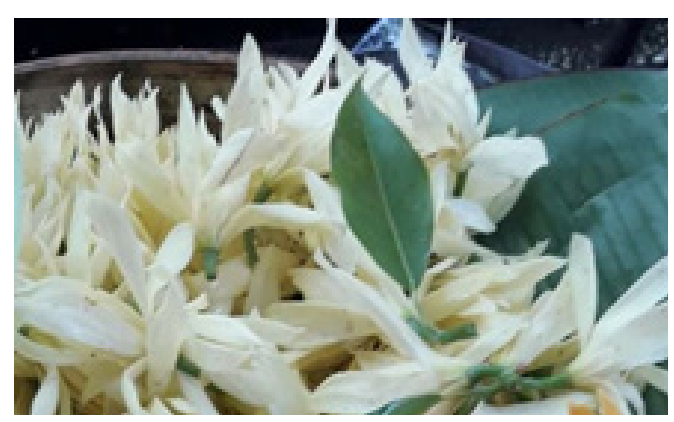

Foto 3. Bunga Cempaka Putih

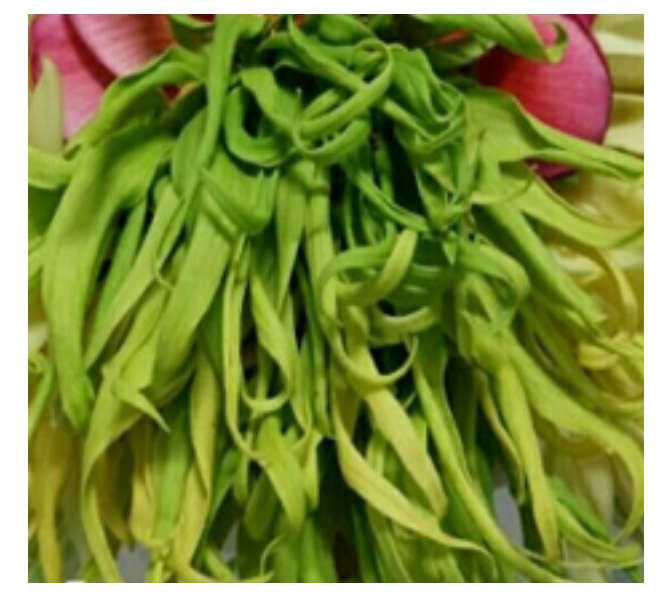

Foto4. Bunga Kenanga

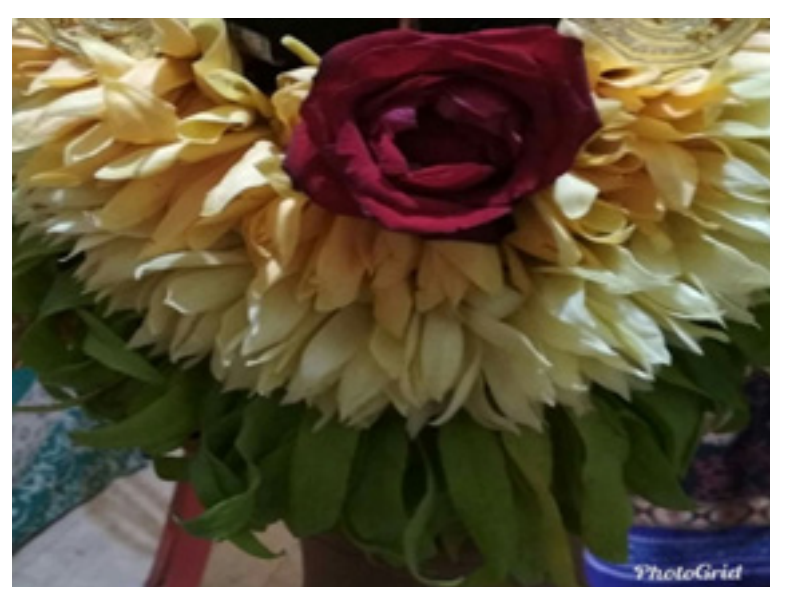

Foto 5. Rangkaian Bunga Payas agung 


\section{Pengaruh Simbol Tri Murti dalam Payas Agung Pengantin}

\section{Estetika Dalam Seni Tata rias Bali}

Keindahan atau disebut dengan Estetika memang sangat terkait dengan wujud sebuah karya seni. Dalam sebuah karya yang dikatakan Seni, tentunya memiliki nilai estetika yang mampu menjadi sebuah daya tarik dalam sebuah objek, yang memberikan pengalaman estetis bagi yang menikmatinya. Tata Rias Busana merupakan salah satu unsur seni yang dapat di lihat ( visual ) dan memiliki nilai keindahan yang tinggi. Bali adalah daerah yang berbudaya, memiliki keunikan dan identitas sendiri, yang sering menjadi daya tarik untuk di kaji lebih dalam. Seni Tata Rias dan Busana yang berkembang di masa kini kian memberikan ruang kreatifitas bagi pelaku dan penikmat seni, khususnya seni tata rias dan busana. Membicarakan nilai keindahan dalam seni sangat relevan, karena nilai ini merupakan penonjolan yang terjadi dalam sebuah bentuk kesenian yang dapat dirasakan bagi manusia yang melihat dan menikmatinya. Nilai keindahan atau Estetika bisa saja secara visual dinikmati dan akhirnya memberikan rasa kepuasan terhadap objek yang dilihat, sehingga objek tersebut layak disebut dengan Seni. Nilai Estetika yang terkandung tidak saja mampu memberikan rasa indah dan nikmat bagi yang mengalaminya, namun nilai keindahan juga dapat memberikan pencapaian pesan yang muncul dari sebuah objek.

Menjadi terlihat cantik dan indah pada hari baik, dimana sepasang pengantin melaksanakan pernikahan adalah impian dan harapan dari kedua mempelai, tidak hanya pengantin wanita, namun pengantin pria juga diharapkan tampil indah dan berwibawa. Kecantikan dan ketampanan akan memberikan nilai keindahan baik secara fisik maupun psikikisnya. Tampil dengan balutan Payas Agung Pengantin Bali tentunya tidak hanya dibutuhkan secara tampilan fisik, namun lebih pada tampilan dalam yang nantinya akan berpengaruh terhadap psikologi kedua mempelai. Setiap manusia menginginkan hal yang terbaik dalam bidang apapun, begitupula dalam tampilan berbusana dan berhias, tentunya menginginkan yang tampak terindah, sehingga mendapatkan kepuasan dan kenikmatan secara dalam. Tata Rias dan Busana yang dikenakan dengan baik dan indah, tentu saja memberikan nilai estetika yang tinggi yang diharapkan dapat memberikan rasa indah dan nyaman bagi penggunanya, dalam hal ini adalah mempelai pengantin, dimana dengan busana indah yang digunakan dapat memberikan aura yang baik dan positif dalam menjalankan upacaranya. Ketika pengantin terlihat cantik dan indah, tentu saja rasa nyaman dan kepercayaan diri yang tinggi dapat memberikan pancaran aura yang baik, dan niscaya akan memberikan nilai religius yang tinggi sehubungan dengan upacara yang dilaksanakan. Keindahan dari busana yang dikenakan oleh pengantin merupakan busana yang terdiri dari unsur- unsur warna seperti kain yang dikombinasikan dengan indah, maka akan menghasilkan perpaduan warna yang cantik, agung, sehingga berpengaruh terhadap tampilan pengantin yang digambarkan bagaikan raja dan ratu.

\section{Taksu}

Bali merupakan daerah yang memiliki keunikan tersendiri, baik alam maupun masyarakatnya. Budaya dan Agama Hindu di Bali sangatmenyatudanmenjadinadi dari setiaplangkah kehidupan masyarakat Bali. Banyak tersimpan halhal yang dikatakan misterius secara sosio- budaya masyarakat Bali yaitu terdapat konsep " Taksu “ yang ada dalam berbagai aspek kehidupan di Bali. Masyarakat Bali pada umumnya percaya dengan adanya Taksu, yaitu kekuatan suci Tuhan yang dapat membangkitkan dan meningkatkan daya kreativitas, intelektualitas seseorang, tidak hanya dalam aspek kesenian, namun dalam kehidupan bidang profesi lainnya, seperti guru, dokter, pebisnis, maupun politikus. Keyakinan yang ada adalah bahwa Taksu bersumber dari Tuhan, sehingga untuk mendapatkan Taksu, manusia senantiasa mengerjakan sesuatu dengan benar, dan selalu memohon, berserah diri kehadapanNya.

Dalam budaya Hindu di Bali dilaksanakan Panca Yadnya sebagai bagian dari persembahan terhadap Tuhan yang merupakan keyakinan dari 
masyarakat Hindu dan tetap dilaksanakan hingga sekarang. Salah satunya adalah upacara Yadnya Perkawinan Hindu yang dilaksanakan di Bali dengan tradisi yang ada di masing- masing daerah di Bali. Dalam Upacara ini terdapat sarana dan prasarana yang digunakan sebagai simbolisasi makna yang terkandung di dalamnya. Sarana dan prasarana upacara terkait juga dengan kesenian yang menjadi sebuah pelengkap kesempurnaan dalam upacara yng dilaksanakan. Payas Agung Pengantin Bali adalah salah satu bentuk sarana yang digunakan dalam upacara Pawiwhan Hindu di Bali, dimana busana ini biasanya digunakan pada upacara Widhi widani atau puncak hari pernikahan. Busana ini pada awalnya hanya dikenakan pada kalangan kerajaan, pada jamannya. Namun seiring waktu hingga kini, Payas Agung digunakan oleh segala kalangan yang melaksanakan upacara perkawinan adat Bali.

Payas Agung Pengantin Bali memiliki identitas, baik bentuk maupun filosofi dari setiap unsur- unsur pembentuknya. Mulai dari hiasan kepala, badan, sampai bagian kaki mempunyai bentuk, warna dan makna yang terkandung. Selain bentuk, payas agung memiliki makna kehinduan dari sisi proses pembentukan, baik dalam mengenakan busana maupun proses sebelum menggunakan busananya. Seperti yang menjadi tradisi di Puri- puri yang ada di daerah Gianyar, Ubud dan di Puri- puri lain yang ada di Bali, tentunya yang masih menjaga tradisi tersebut, melaksanakan sebuah ritual sehari sebelum upacara pernikahan. Seorang penata rias tradisional yang dipercaya sebagai perias Payas Agung di Puri puri yang ada di daerah Gianyar menyebutkan bahwa ritual yang dilaksanakan adalah ritual sehari sebelum pengantin wanita mengenakan busana Payas Agung, maka calon pengantin wanita biasanya dibalurkan lulur tradisional yang terbuat dari bunga gumitir berwarna kuning, agar keesokan harinya kulit sang pengantin terlihat bersih kekuningan ( Kuning Gading). Selain itu sebelum memulai menggunakan makup, bulu wajah akan dibersihkan, seperti alis, dan bulu halus dibagian kening atas. Hal ini sebagai simbolisasi kedewasaan seorang wanita dalam mengarungi kehidupan perkawinan nanti. Bagi sang pinata rias juga memiliki ritual sebelum memulai merias, berawal dari sebelum berangkat ke tempat upacara, seorang penata rias senantiasa bersembahyang memohon keselamat, kelancaran dan ketaksuan dalam menjalankan pekerjaannya merias seorang pengantin. Hal ini dilakukan agar sang perias senantiasa dilindungi Tuhan, dan segala yang dikerjakan dapat berjalan dengan lancer tanpa hambatan baik sang perias maupun sang pengantin. untuk mendapatkan hasil yang maksimal tentunya sang perias harus mempersiapkan diri dengan baik, dan mempersiapkan alat- alat yang akan digunakan. Menurut Ayu Ketut Rahayuning, seorang penata Rias tradisional Bali, kesiapan dalam merias sangat penting, mulai dari fisik, pikiran, dan alat yang akan digunakan dalam merias. Menurutnya, hasil rias Payas Agung Pengantin Bali akan terlihat bagus dan sempurna tidak hanya terlihat dari bentuk dan cara pemasangan busananya saja, namun lebih pada aura yang muncul dari pengantin setelah rias dan busana nya dikenakan. Hal ini tentunya diperlukan restu dan energi niskala yang diperoleh dari Tuhan. Pengantin yang terlihat cantik dan anggun bagaikan putri kerajaan tidak hanya karena bentuk, warna dan asesoris yang digunakan,namun ada pancaran sinar yang lain yang terlihat dari pengantin, inilah yang dikatakan riasan Pengantin yang metaksu. ( Wawancara, Denpasar, 1 november 2017 ). Sebagai Penata rias yang baik, tentunya merasa berhasil, ketika karya yang dihasilkan berjalan lancar dan terwujud sesuai dengan harapan, sehingga rasa kepuasan pun akan didapatkan.

Keberadaan bunga sebagai simbol Tri Murti dalam Payas Agung merupakan perwujudan rasa bhakti manusia, dalam hal ini pengantin yang melaksanakan upacara yadnya, tentu saja mempersembahkan hal terbaik. Bunga sebagai simbul Dewa tentu saja diletakkan di bagian kepala yang merupakan bagian tertinggi dalam tubuh manusia. Dalam hal ini, bunga yang digunakan adalah bunga yang segar, beraroma harum, sehingga berpengaruh pula pada aura sang pengantin. Menurut Ayu Rahayuning ( 
Wawancara, Denpasar 6 November 2017), menggunakan bunga segar tentu saja akan memancarkan keindahan, energi yang positif dari wangi bunga yang ditimbulkan, aura kecantikan terhadap pengantinnya.

\section{PENUTUP}

Keberadaan simbol Tri Murti dalam Payas Agung Pengantin Bali digambarkan pada bagian hiasan kepala, yaitu pada bunga segar cempaka putih, kuning, dan kenanga yang diranngkai sedemikian rupa, dipasangkan pada hiasan kepala bagian belakang, dimana dari letaknya yang dihubungkan pada estetika hindu, yaitu bagian yang paling disucikan manusia adalah bagian atas ( kepala) sebagai perwujudan simbol Sang Hyang Widhi dalam manifestasinya sebagai Tri Murti yang disucikan.

Simbol Tri Murti dalam Payas Agung Pengantin Bali yang digunakan oleh pengantin dapat berpengnaruh dalam keindahan ( Nilai Estetika ) dari tampilan pengantin yang indah, sehingga rasa yang timbul adalah rasa nyaman dan kepuasan terpengaruh pula terhadap kepercayaan diri dari pengantin. sehingga wujud syukur dan bhakti terhadap Ida Sang Hyang Widhi dapat tercipta dengan baik. Selai nilai etetka, nilai Taksu yang umumnya dipercaya keberadaannya oleh masyarakat Hidu di Bali dapat diwujudkan dalam simbol Tri Murti yang ada dalam Payas Agung Pengantin Bali. Bunnga segar yang digunakan dan diletakkan pada bagian yang disucikan sebagai persembahan dalam upacara yang dilaksanakan, dapat memberikan aura positif, dan aura kecantikan yang muncul dari mempelai ( Pengantin ). Simbol Tri Murti yang dilambangkan dengan penggunaan bunga cempaka putih, kuning dan kenannga yang tentunya digunakan bunnga segar yang harum dan utuh diranngkai dengan indah, mampu memberikan aura baik dari bentuk, wangi dan nilai filosofinya, sehingga memancarkan Taksu bagi pengantin yang mengenakannya.

\section{Saran}

Banyaknya kemunculan penata rias Bali yang semakin menjadi trand di masyarakat adalah hal yang baik dan positif bertujuan sebagai perkembangan seni tat arias Bali. Namun mengingat Tata Rias Busana Adat Bali merupakan bagian dari budaya tradisi yang perlu dilestarikan, maka sangat diperlukan kajian- kajian yang bertujuan sebagai referensi pelestarian budaya, khususnya seni Tata Rias tradisi, agar tidak menghilangkan nilai atau makna filosofis yang terkandung didalamnya. Hal ini adalah sebagai salah satu upaya menjaga kelestarian budaya sebagai warisan leluhur yang dapat dibanggakan seterusnya.

\section{DAFTAR PUSTAKA}

Agung, AA Ayu Ketut. 2004. Busana Adat Bali. Denpasar : Pustaka Bali Post

Arikunto, Suharsini, 2002. Prosedur Penelitian,suatu pendekatan Praktek, Rineka Cipta

Artadi, I Ketut, 2004. Nilai Makna dan Martabat Kebudayaan. Semarang : Indrajaya

Atmaja. 2002, Metode Penelitian Kuallitatif. Singaraja : IKIP Negeri.

Bandem, I Made.1983.Ensiklopedia Tari Bali .Denpasar : Akademi Seni Tari Indonesia.

Bandem, I Made. 1996. Wastra Bali. Denpasar : HArtanto Art Books

Dibia, dkk.1999/2000.Tari Wali ( sanghyang , Rejang, Baris ). Denpasar: Dinas Kebudayaan Provinsi Daerah Tingkat I bali.

Dibia, I Wayan. 2012. Taksu. Denpasar: Bali mangsi Foundation

Dwija, I Wayan. 2006. Metodologi Penelitian Pendidikan. Amlapura :STKIP Agama Hindu.

Djelantik. 1990. Pengantar Dasar Umum Estetika. Denpasar : Sekolah Tinggi Seni Indonesia.

1999. Estetika Sebuah Pengantar Seni Pertunjukan. Bandung: Masyarakat Seni Pertunjukan Bandung.

Koentjaraningrat,1980.Sejarah Teori Antropologi I.Jakarta : Universitas Indonesia.

Mantra , Ida Bagus. 1993. Bali Masalah Sosial 
dan Modernisasi. Denpasar : Upadha Sastra.

Maleong, Lexy J. 1990. Metodologi Penelitian Kualitatif.Bandung : remaja Rosdakarya.

Milles, Matthew B,A, Michael Huberman. 1992. Analisis Data Kualitatif.Jakarta : Universitas Indonesia.

Martami, Ny M, 1993. Tata Rias Pengatin Bali. Denpasar : Upada Sastra

Miarta Putra, I Nyoman. 2009. Mitos- mitos Tanaman Upakara. Denpasar : Pustaka MAnikgeni

Oka Arwati Ngoerah, IGA, 1997. Sanggul Bali. Denpasar : Upada Sastra

Putra, I Gusti A Gede. 1980. Cudamani Tari Wali. Denpasar : Percetakan Bali.

Yin, Robert.K. 2000. Studi kasus ( Desain dan Metode ) Jakarta : PT.Grafindo Persada.

Yudha Triguna, Ida Bagus Gde. 2000. Teori Tentang Simbol. Denpasar : Widya Dharma. 